Sri Lanka J. Aquat. Sci. 13 (2008): 95-108

\title{
Vegetation structure and potential gross primary productivity of mangroves at Kadolkele in Meegamuwa (Negombo) estuary, Sri Lanka
}

\author{
J.M.A.L. JAY AKODY, M.D. AMARASINGHE ${ }^{1 *}$, V . \\ PAHALA W A TTAARACHCHIAND K.H.W .L. DE SIL V A' \\ ${ }^{1}$ Department of Botany, University of Kelaniya, Kelaniya, Sri Lanka. \\ ${ }^{2}$ National Aquatic Resources Research and Development Agency, \\ Negombo, Sri Lanka. \\ *Corresponding author (E-mail: mala@kln.ac.lk)
}

\begin{abstract}
The potential gross primary productivity of the mangrove stands at Kadolkele in Meegamuwa (Negombo) estuary was studied in relation to vegetation structure with a view to understanding the salient structural components that affect functioning of mangrove ecosystems. Structure of mangrove stands under study was characterized with plant species richness, plant (stem) density, frequency of occurrence of constituent species, plant basal area and height. The structural complexity index values calculated from above parameters revealed a statistically significant $(\mathrm{p}<0.01)$ positive relationship with the potential gross primary productivity of the mangrove stands that has been calculated using data on absorption of photosynthetically active radiation (PAR) by the stands that were measured using a light meter with a quantum sensor. Leaf area index (LAI) values were calculated using absorption data and potential gross primary productivity was estimated using an assimilation coefficient. Mean values of structural parameters were used to ordinate the mangrove sites through principal component analysis. Ordination showed a productivity gradient among the mangrove sites where species richness, stem density, plant height and leaf area index were the key factors that affect potential gross primary productivity of mangrove stands.
\end{abstract}

\section{Introduction}

Primary production of mangroves, a group of salt-tolerant plants that thrive in tropical inter-tidal areas provide a significant source of energy for aquatic food webs (Day et al. 1987; Amarasinghe and Balasubramaniam 1992b). Mangroves are well adapted to the inter-tidal conditions and 
therefore are evident to be highly productive. Mangrove productivity however has shown a wide variation among sites (Brown and Lugo 1982; Amarasinghe and Balasubramaniam 1992b). Apart from climatic, edaphic, hydrological and anthropogenic factors, mangrove forest structure may have an effect on their primary productivity as it has a direct relevance to its photosynthetic capacity. The extent of photosynthetic surface (leaf area) is a critical factor that may affect gross primary productivity (Okimoto et al. 2007). The solar zenith angle, which is a function of time, day number and latitude also plays a part in determining the total quantum of photosynthetically active radiation (PAR) absorbed by plant leaves. When angle of the sun is not vertical, solar radiation passes though more leaves and thus the potential for absorbing PAR by the leaves vary accordingly.

$\mathrm{V}$ egetation structure is determined by the species diversity, relative densities of constituent species, overall density of the stand, basal area that represents the size of the plant stem/s and their height. Primary productivity that has a bearing on canopy size, foliar volume and density in turn are species-dependent, thus structure of a vegetation provides an indication of its functional capacity which has a bearing on fisheries, forestry and global climate change due to potential high carbon sequestration (Ong et al. 1995). Present study was conducted with the objective of determining the salient structural parameters that affect the potential gross primary productivity of the mangrove stands at Kadolkele in Meegamuwa estuary, Sri Lanka.

\section{Materials and Methods}

\section{Study area}

Kadolkele mangrove area forms part of Meegamuwa estuary, located on the west coast of Sri Lanka. Mangroves cover approximately 350 ha (Pahalawattaarachchi and Amarasinghe 1995) and the largest extent occurs in the northern part of the estuary that opens up to the Indian Ocean. Kadolkele is situated on the northeastern shore of the estuary and covers approximately 15 ha of the inter-tidal zone (Figure 1).

\section{Vegetation structure}

Structural data, i.e. species diversity, density, basal area and plant height were obtained from three belt transects of $10 \mathrm{~m}$ wide and $50 \mathrm{~m}$ long that were laid perpendicular to the shoreline. Density of stems, frequency of occurrence, height and basal area of constituent species were measured using standard methods and relative density, frequency and dominance of each species were calculated (Snedaker and Snedaker 1984). Above data were used to calculate complexity index (Holdridge et al. 1971) as shown below. Complexity index (CI) was used as an overall estimate of the structural complexity of the vegetation in sample plots and it was calculated as below.

$\mathrm{CI}=$ Species richness $\mathrm{x}$ stand density $\mathrm{x}$ stand basal area $\mathrm{x}$ stand height $\times 10^{5}$. 


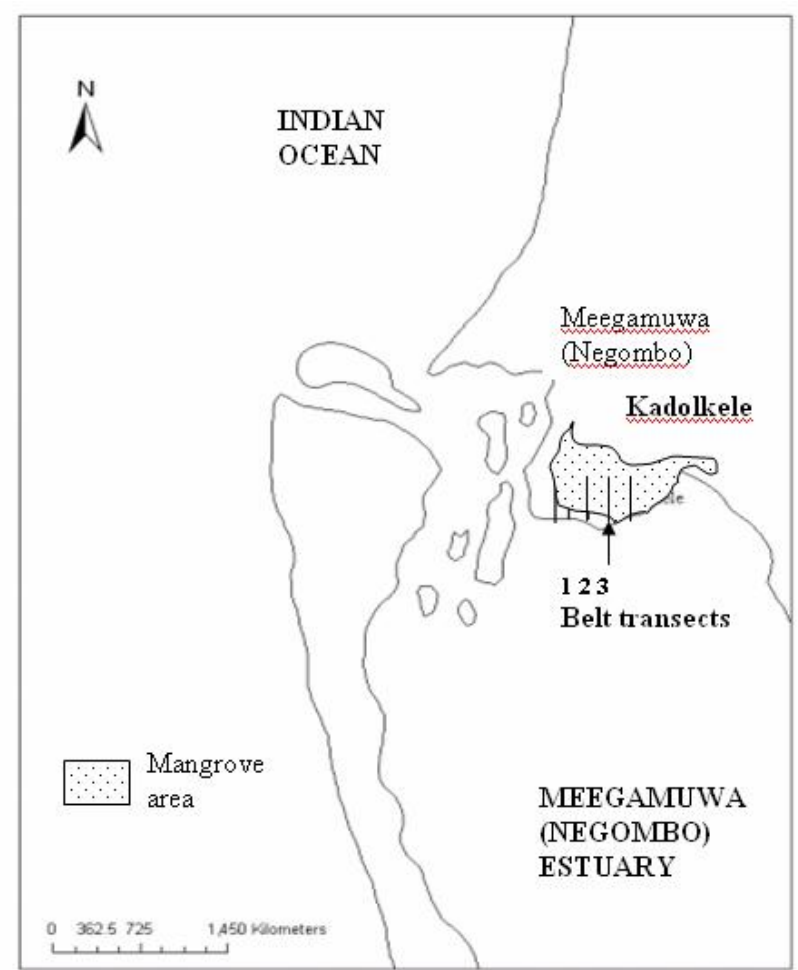

Figure 1. Location of the study area and sites of Meegamuwa (Negombo) estuary

Approximately 100 readings of I were taken under well developed canopies in each sub-plot and as many as 1000 readings were obtained from sub-plots where the canopy was discontinuous and had numerous gaps. Approximately 100 readings of PAR were taken within 30 minutes.

$\mathrm{V}$ alues for zenith angle (angle of the sun from the vertical) for the time during which PAR measurements at each transect were made were obtained from the Meteorological Department in Colombo, Sri Lanka.

Mean values for incident PAR (b) and PAR under the canopy $\left(I_{\text {mean }}\right)$ were calculated for each sub-plot and the values of I(PAR under the canopy) that were greater than $\left(I_{\text {mean }} \times 3\right)$ were considered as those representing the localities of gaps and left out when calculating the revised $I_{\text {mean }}$ for the sub-plots. The same procedure was repeated with the newly calculated $\mathrm{I}_{\text {mean }}$ until no more light meter readings were greater than three times the value of $\mathrm{I}_{\text {nean }}$ calculated last.

Canopy cover $(\eta)$ for each sub-plot was calculated as below.

$\eta=\frac{\text { Remaining number of readings }}{\text { Total number of readings }}$ 
PAR wavelengths the irradiance at the bottom of the canopy is given as follows.

$\mathrm{I}=\mathrm{Io} * \exp \left(-\mathrm{k} * \mathrm{~L}^{1}\right)$

$\mathrm{L}^{1}$ is the apparent leaf area index, because when angle of the sun is not vertical, the solar radiation passes through more leaves therefore leading to an overestimate of leaf area index (L) of the vegetation and $\mathrm{k}$ is canopy light extinction coefficient. Therefore,

$$
\mathrm{L}^{1}=\frac{\ln (\mathrm{I} / \mathrm{Io})}{-\mathrm{k}}
$$

Leaf area index (L) has to be derived by correcting $\mathrm{L}^{1}$ for the solar zenith angle at the time that the measurement $\mathrm{s}$ of Io and I were made and therefore,

$$
\mathrm{L}=\mathrm{L}^{1} * \cos (\theta \mathrm{r}) \eta
$$

Where $\theta \mathrm{r}$ is the zenith angle in radians, $\eta$ is the canopy cover expressed as a ratio.

$$
\cos \theta \mathrm{r}=\cos (\theta \pi / 180)
$$

The potential gross primary productivity of the canopy per unit area $(\mathrm{R})$ therefore is

$$
\mathrm{P}_{\mathrm{N}}=\mathrm{A} \text {. d. L. }
$$

Where $\mathrm{A}$ is the average rate of photosynthesis $\left(\mathrm{g} \mathrm{C} \mathrm{m}^{-2} \mathrm{hr}^{-1}\right)$ for all leaves in the canopy, $d$ is the day length in hours and $\mathrm{L}$ is the total leaf area index of the canopy.

Rate of photosynthesis (A) for mangroves (in general) during the dry season was taken as $0.216 \mathrm{~g} \mathrm{C} \mathrm{m}^{-2} \mathrm{hr}^{-1}$ while that for the wet season as $0.432 \mathrm{~g} \mathrm{C} \mathrm{m}^{-2} \mathrm{hr}^{-1}$ (Bunt et al. 1979). The $\mathrm{P}_{\mathrm{N}}$ for all the nine sub-plots of the three belt transects during wet and dry periods respectively was calculated and the average was taken to find out the relationship between potential gross primary productivity and structural complexity of mangrove vegetation.

\section{Statistical analysis}

Principal component analysis (PCA) is an ordination method that can be used to identify the underlying structure of multivariate datasets. Accordingly, the structural data collected from 15 plots at Kadolkelle mangrove area were subjected to PCA. All the structural parameters selected for PCA analysis were then $\mathrm{Ln}(\mathrm{x}+1)$-transformed in order to reduce the non-normality of the data. The PCA was performed using MINIT AB 14. The scores of the PC1 axis were then plotted against the potential gross primary productivity values gathered from the 15 plots. 


\section{Results}

Mangrove stand density, basal area, height and species richness for the 15 sub-plots of the three belt transects employed for the study are graphically represented in Figure 2. As indicated by the values for complexity index, structural complexity of the vegetation gradually decreases towards the estuarine shoreline. Avicennia marina dominates Kadolkele mangroves whileAegiceras corniculatum was found to be rare (Table 1). The leaf area index values and the potential gross primary productivity calculated for the 15 sub-plots reveal that the magnitude of productivity during the rainy (wet) period is greater than that of the relatively dry period (Table 2 ). A statistically significant positive relationship was revealed between diversity complex and potential gross primary productivity $\left(\mathrm{P}_{\mathrm{N}}\right)$ (Figure 3$)$.

The positive relationship that was revealed to exist between PGPP and leaf area index also was statistically significant $(\mathrm{p}<0.01)$. Potential gross primary productivity and structural complexity however, declined along the gradient from estuarine shore towards land (Figure 4).

Table 1: Importance value (relative contribution of individual species to vegetation structure) of constituent mangrove plant species of Kadolkele mangrove stand.

\begin{tabular}{lcccc}
\hline \multicolumn{1}{c}{ Species } & $\begin{array}{c}\text { Relative } \\
\text { density }\end{array}$ & $\begin{array}{c}\text { Relative } \\
\text { frequency }\end{array}$ & $\begin{array}{c}\text { Relative } \\
\text { dominance }\end{array}$ & $\begin{array}{c}\text { Importance } \\
\text { value }\end{array}$ \\
\hline $\begin{array}{l}\text { Aegiceras } \\
\text { corniculatum } \\
\text { Avicennia marina }\end{array}$ & 0.02 & 0.9 & $2.9568 \times 10^{-3}$ & 0.11 \\
$\begin{array}{l}\text { Excoecaria agallocha } \\
\text { Lumnitzera racemosa }\end{array}$ & 0.46 & 0.32 & 0.66 & 1.44 \\
$\begin{array}{l}\text { Rhizophora } \\
\text { mucronata }\end{array}$ & 0.23 & 0.25 & 0.17 & 0.23 \\
& 0.25 & 0.17 & 0.15 & 0.65 \\
\hline
\end{tabular}



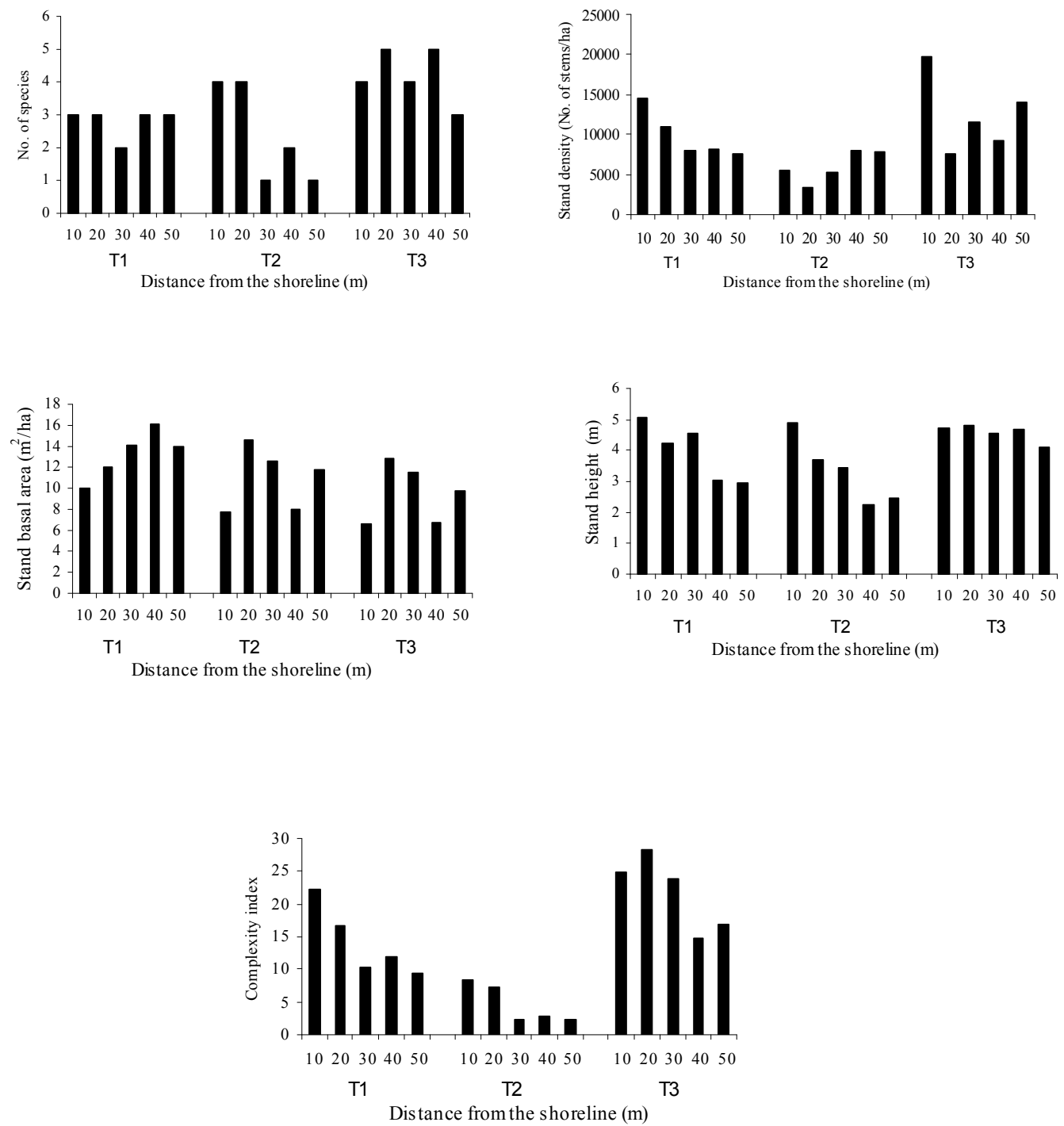

Figure 2. Variation of structural parameters (no. of species, stand density, stand basal area, stand height and complexity index) among the sub-plots (0 $-10 \mathrm{~m}, 10-20 \mathrm{~m}, 20-30 \mathrm{~m}, 30-40 \mathrm{~m} \& 40-50 \mathrm{~m})$ of the three transects $(\mathrm{T} 1, \mathrm{~T} 2 \& \mathrm{~T} 3)$ at Kadolkele mangrove area. 
Table 2. Potential gross primary productivity $\left(\mathrm{P}_{\mathrm{N}}\right)$ of the mangrove stand at Kadolkele, Negombo estuary, during wet and dry periods. $\quad \mathrm{I}_{0}$ - Incident PAR, I - PAR under the canopy, $\theta$ - Solar zenith angle, $\eta-$ Canopy cover expressed as a ratio, $\mathrm{L}^{1}-$ Apparent leaf area index, L - Leaf area index.

\begin{tabular}{|c|c|c|c|c|c|c|c|c|c|c|c|c|c|c|c|c|}
\hline transect & $\begin{array}{l}\text { Sub- } \\
\text { plot }\end{array}$ & \multicolumn{7}{|c|}{ Wet period (Southwest monsoon) } & \multicolumn{7}{|c|}{ Dry period (Inter-monsoon) } & $\begin{array}{c}\text { A verage } \\
\mathrm{P}_{\mathrm{N}} \\
\mathrm{t} / \mathrm{ha} / \mathrm{yr}\end{array}$ \\
\hline \multirow[t]{4}{*}{1} & 1 & & 555.5 & & 1 & 5.27 & 2.02 & 33.22 & & 808.4 & & 1 & 4.91 & 0.77 & 7.28 & 20.25 \\
\hline & 3 & 7748.1 & 745.7 & $67^{0} 25$ & 1 & 4.68 & 1.8 & 34.05 & 9.321 & 980.7 & $81^{0} 01^{1}$ & 1 & 4.53 & 0.71 & 6.72 & 20.39 \\
\hline & 4 & & 677.4 & & 1 & 4.87 & 1.87 & 35.38 & & 1296.6 & & 0.99 & 3.97 & 0.61 & 5.77 & 20.58 \\
\hline & 5 & & 824.9 & & 0.98 & 4.48 & 1.69 & 31.97 & & 1266.3 & & 0.99 & 4.02 & 0.62 & 5.87 & 18.58 \\
\hline \multirow{4}{*}{2} & 2 & & 468.6 & & 1 & 5.35 & 1.32 & 24.98 & & 714.5 & & 0.99 & 5.2 & 0.63 & 5.96 & 15.47 \\
\hline & 3 & 6791.3 & 730.4 & $75^{0} 42$ & 1 & 4.46 & 1.10 & 20.81 & 9759.2 & 1306 & $83^{0} 02^{1}$ & 1 & 4.02 & 0.49 & 4.63 & 12.72 \\
\hline & 4 & & 634 & & 1 & 4.74 & 1.17 & 22.14 & & 1256.4 & & 0.98 & 4.01 & 0.47 & 4.45 & 13.30 \\
\hline & 5 & & 699.3 & & 1 & 4.54 & 1.12 & 21.19 & & 1449.7 & & 1 & 3.81 & 0.46 & 4.35 & 12.77 \\
\hline 3 & 1 & & 327.4 & & 1 & 6.26 & 1.47 & 27.81 & & 394.7 & & 0.98 & 6.34 & 1.99 & 18.83 & 23.32 \\
\hline
\end{tabular}




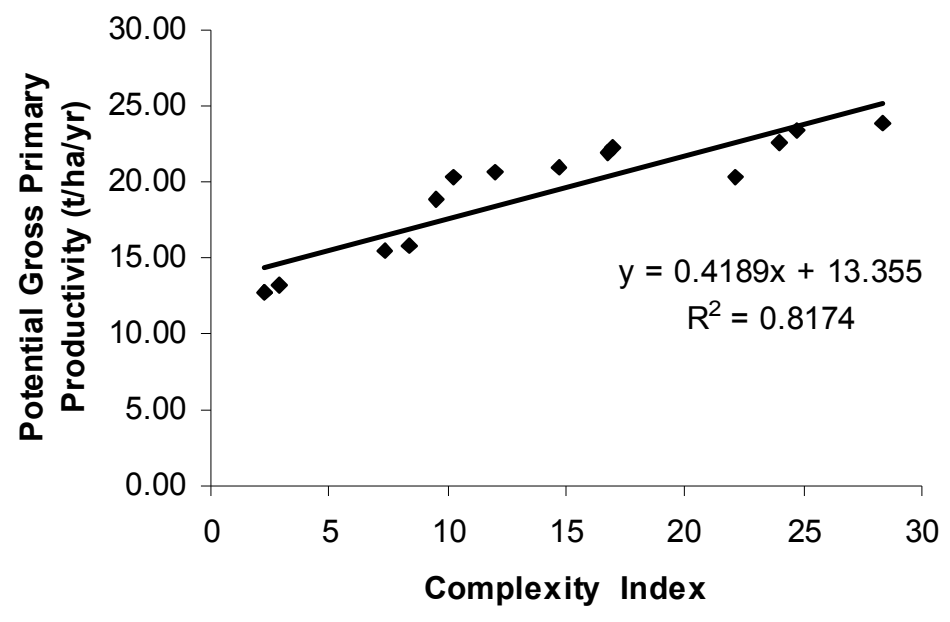

Figure 3. Relationship between structural complexity and potential gross primary productivity of Kadolkele mangrove stand

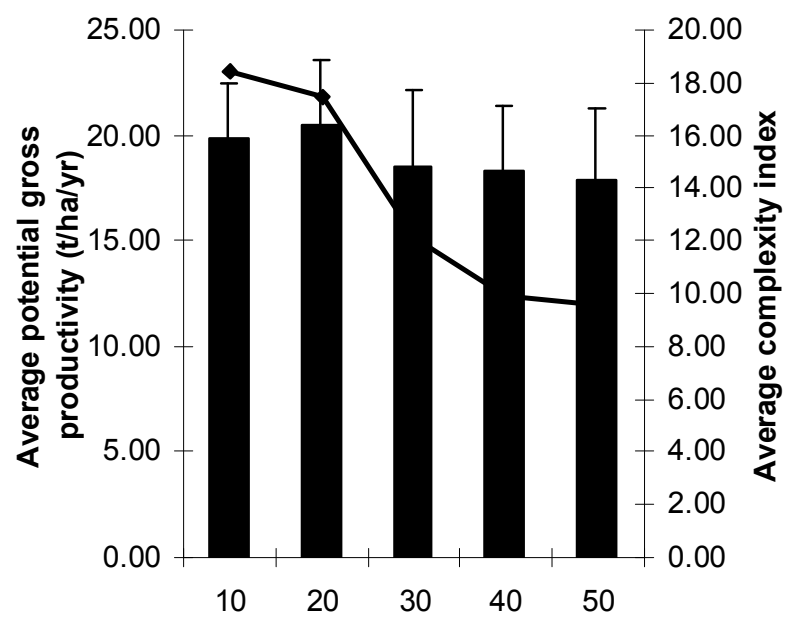

Distance from the shore line $(\mathrm{m})$

Productivity $\multimap$ Complexity index

Figure 4. V ariation of average potential gross primary productivity and average structural complexity along the gradient from estuary towards land 
The PCA score plot of the first two principal component axes shows the first two principal component axes (PC1 and PC2) explain the cumulative variances of $56.7 \%$ and $77.5 \%$ respectively while PC3 explains $91.7 \%$ of the cumulative variance (Figure 5, Table 3) among the dataset. The negative loading along the PC1 axis was related to high stand density, number of species, plant height and leaf area index while the positive loading on the same axis was related to high basal area. On the PC2 axis, the negative loading was related to high stand basal area and number of species, while the positive loading was related to stand density. Accordingly, when PC1 scores are considered, mangrove plots with negative scores represent more productive areas than those with positive PC1 scores (Figure 6).

Table 3. The final results of the principal component analysis of vegetation structural parameters in 15 plots from Kadolkele mangrove area.

\begin{tabular}{lccccc}
\hline Parameter & PC1 & PC2 & PC3 & PC4 & PC5 \\
\hline Eigen value & 2.8353 & 1.0380 & 0.7131 & 0.3682 & 0.0454 \\
& & & & & \\
$\begin{array}{l}\text { \% variance } \\
\text { explained }\end{array}$ & 0.567 & 0.208 & 0.143 & 0.074 & 0.009 \\
Cumulative \% & 0.567 & 0.775 & 0.917 & 0.991 & 1.000 \\
variance explained & & & & & \\
V ariables & & & & & \\
$\quad$ No. of species & -0.464 & -0.408 & 0.349 & 0.575 & 0.407 \\
$\quad$ Stand density & -0.402 & 0.546 & -0.556 & 0.062 & 0.477 \\
$\quad$ Stand basal area & 0.295 & -0.655 & -0.654 & 0.003 & 0.236 \\
$\quad$ Stand height & -0.485 & -0.288 & 0.129 & -0.797 & 0.174 \\
$\quad$ Leaf area index & -0.548 & -0.153 & -0.353 & 0.174 & -0.722 \\
\hline
\end{tabular}

\section{Discussion}

Among the five species encountered in the sampling sites, Avicennia marina, a pan-tropical mangrove species that is found to occur under a wide range of edaphic conditions, dominates Kadolkele mangroves. Rhizophora mucronata occupies the water-front zone boardering either the shoreline of the estuary or the banks of the creeks within mangals (area covers with mangrove plants) whileLumnitzera racemosa was found to occur most frequently confines to the landward margin of the mangal. 


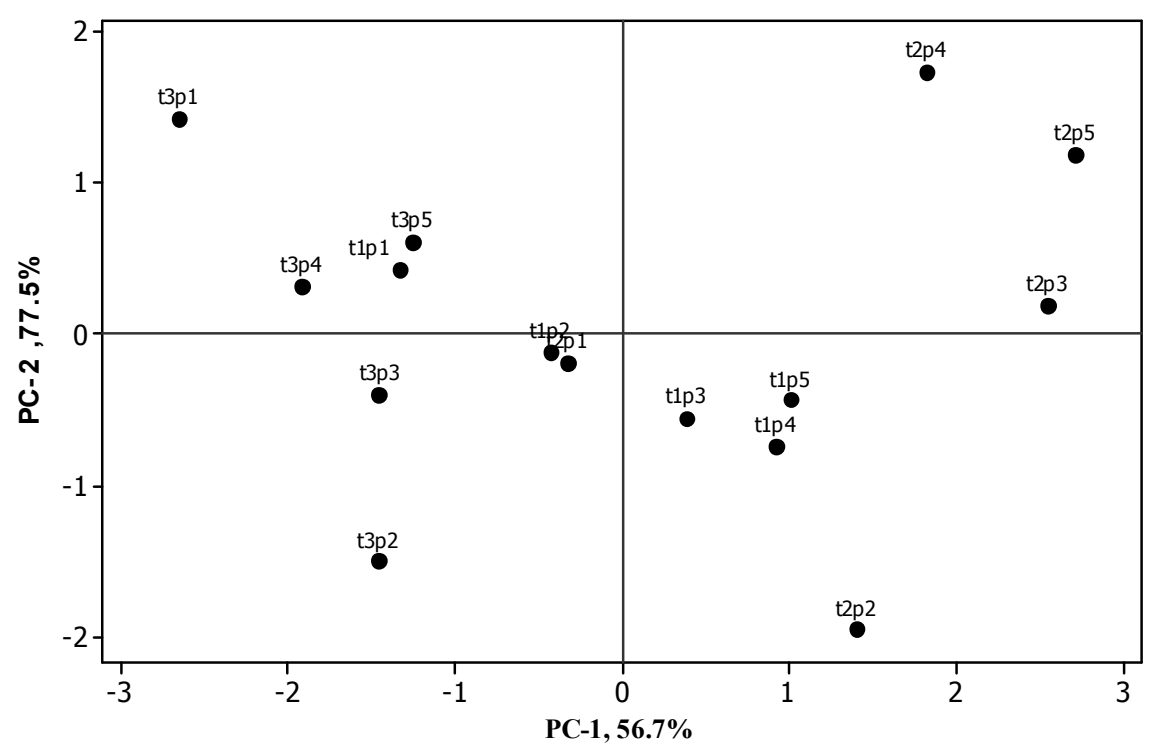

Figure 5. The final principal component analysis plot of the vegetation structural characteristics of 15 plots at Kadolkelle mangrove area. ( t1p1 $\mathrm{t} 1 \mathrm{p} 5$ - sub plots of transect $1, \mathrm{t} 2 \mathrm{p} 1-\mathrm{t} 2 \mathrm{p} 5-$ sub plots of transect 2 , $\mathrm{t} 3 \mathrm{p} 1-\mathrm{t} 3 \mathrm{p} 5-\mathrm{sub}$ plots of transect 3.)

Complexity index values derived for Kadolkele were greater than those for mangals of Puttalam lagoon and Dutch bay (Amarasinghe and Balasubramanium 1992a) and undisturbed mangals of Chilaw lagoon (Pambala) (Jayasundera et al. 1997). The relatively low $\left(0.6-15 \mathrm{~g} \mathrm{~L}^{-1}\right)$ soil salinities that prevail at Kadolkele (Kahangama 2007), supported with the surface runoff that it receives during rainy periods apparently provides a conducive inter-tidal environment for mangroves at Kadolkele. Unlike the other mangrove areas on the west coast, such as those around Galle, Kadolkele received considerable protection for the past two decades, since it came under custody of the National Aquatic Resources Research and Development Agency (NARA) and hence the vegetation is hardly disturbed.

Despite the declining soil salinities towards land (Kahangama 2007), the structural complexity of mangrove stand was revealed to decrease along the gradient (Figure 3). Structural data exemplifies that the high numbers of species, densities and heights occur at the areas close to the shoreline that get inundated with estuarine waters most frequently than in the landward areas that are dominated by A. marina. Absence of species such as $R$. mucronata with relatively large and heavy propagules in the landward areas of less salinity may be attributed to failures in recruitment due to prevalent weak tidal currents that do not support dispersal of heavy 
propagules. Nevertheless small propagules of species such as $L$. racemosa and E. agallocha apparently are dispersed more inland with water. Records (Rabinowotz, 1978; Delgado et al. 2001) to reveal that dispersal properties of mangrove species correlate with the spatial distribution of adults within the mangal and that propagule buoyancy, availability, dispersal, and the effect of water movement on propagule anchoring limit, apart from predator pressure, are responsible for natural zonation of species in a mangal. Species that naturally occur in more landward positions of the intertidal zone have small propagules that require a period of freedom from tidal inundation of approximately five days in order to establish firmly in the substrate while species at the water-front areas have large, heavy propagules. Geomorphology and hydrology that is determined by local geology, sea-level change, tide, freshwater inputs, shoreline structure, watershed morphometry, groundwater influence, natural disturbance regimes, and climate contribute to the physico-chemical gradients which in turn govern the structure and function of the inter-tidal ecosystems (Woodroffe 1993).

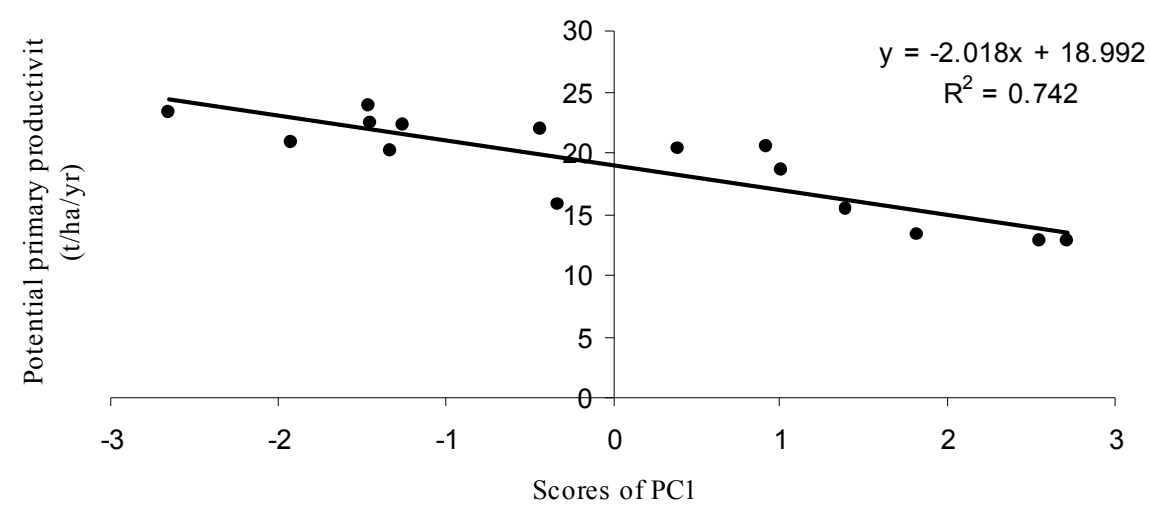

Figure 6. The relationship between PC1 scores and potential gross primary productivity of mangroves at Kadolkelle

The potential gross primary productivity of mangrove plots was negatively correlated $(\mathrm{p}>0.01)$ with the PC1 scores(Figure 6). The greater potential gross primary productivity (PGPP) observed in the rainy period (Table 3) may be explained as a result of enhanced nutrient input from surface runoff and decreased soil salinity that in turn may lead to low leaf fall in comparison to dry period thus resulting relatively a high leaf area index (LAI). Photosynthetic capacity of mangrove leaves however depends on their relative location in the canopy as it affects the leaf morphology, anatomy and physiology. Lugo et al.(1976) reported that the photosynthetic rate of sun leaves of Rhizophora mangle and Avicennia germinance, that are 
small in size and occupy the upper part of the canopy and therefore possess a thick cuticle and tannin cells that protects them from heat and UV radiation, is twice as that of shade leaves which occupy the lower strata of the canopy and thus are larger in size with a thin cuticle and more chlorophyll. Besides, the respiration rate of the latter at night is four times greater than that of the sun leaves, hence are inferior fixers of carbon. During the dry periods, sun leaves tend to fall and that exposes the shade leaves to hot sun, thus causing their fall too. Leaf fall rates have been observed to be significantly greater during dry period than in the wet period (Amarasinghe and Balasubramaniam 1992b; Pahalawattaarachchi 1998) which in turn reduces LAI and the PGPP of the mangrove stand. Besides, reduction of leaf size has been observed to be the initial morphological reaction to environmental stress on plants (Parida and Das 2005) and therefore relatively high salinity during the months of low rainfall may cause stress on mangroves, resulting lower PGPP than in the rainy months.

Structure of the mangrove vegetation as represented by the complexity index values show a strong positive relationship $(p>0.01)$ with the PGPP measured for the stand (Figure 2). Similar trends have been discerned for the mangrove stands in Puttalam lagoon and Dutch bay of Sri Lanka (Amarasinghe and Balasubramaniam 1992a). Structural complexity of mangroves also have shown a statistically significant positive relationship with habitat availability in the mangroves, measured in terms of shrimp abundance (Jayasundera et al. 1997).

The PGPP values from the 15 plots were negatively correlated ( $p>0.01)$ to the PC1 scores, indicating that except for stand basal area, other structural variables, i.e. number of species, stem density, frequency of occurrence, plant height and leaf area index have a positive bearing on mangrove PGPP. Linear regression analyses carried out between each structural parameter and PGPP revealed that except for the basal area, all other variables showed a statistically significant positive relationship among them, thus indicating that PGPP of mangrove vegetation is determined to a greater extent by canopy volume and leaf area index than maturity (size of the stems) of the plants. Values for the above structural variables gathered from plots near the shoreline were greater than those for the more inland plots (areas) dominated by $A$. marina trees with larger stems, imply that greater contribution of mangroves, as sources of energy for aquatic food webs, could be achieved through enhancing plant species diversity in a mangal.

\section{References}

Amarasinghe, M.D. \& S. Balasubramaniam, 1992a.

Structural properties of mangrove stands on the north western coast of Sri Lanka. Hydrobiologia 247: 17-27.

Amarasinghe, M.D. \& S. Balasubramaniam, 1992b. 
Net primary productivity of two mangrove forest stands on the north western coast of Sri Lanka. Hydrobiologia 247: 37-47.

Brown, S. \& A.E. Lugo. 1982.

A comparison of structural and functional characteristics of saltwater and freshwater forested wetlands. In: Wetlands Ecology and Management (B. Gopal, R.E. Turner, R.G. Wetzel \& D.F. Whigham eds.), pp.109-130, International Scientific Publications, Jaipur, India.

Bunt, J.S., K.G. Boto \& G. Boto, 1979.

A survey method for estimating potential levels of mangrove primary production. Marine Biology, 52: $123-128$.

Day, J.W. Jr., W.H.Conner, F. Ley-Lou, R., Day \& A. Machado, 1987.

The productivity and composition of mangrove forests, Laguna de Terminos, Mexico. Aquatic Botany, 27:267-284.

Delgado P., P. F. Hensel J. A. Jiménez \& J. W . Day, 2001.

The importance of propagule establishment and physical factors in mangrove distributional patterns in a Costa Rican estuary. Aquatic Botany 71 (3) : 157-178.

Holdrige, L.R., W.C. Grenco, W.H.Hathey, T. Liang \& J. Tosi, 1971.

Forest Environment in Tropical Life Zones: A Pilot Study. Pregaman Press, New Y ork: 747.

J.W.K.K Jayasundera, M.D.Amarasinghe \& K.B.Ranawana, 1999.

Mangrove vegetation structure and the abundance of shrimps in Chilaw lagoon (Sri Lanka) Sri Lanka Journal of Aquatic Sciences, 4: $17-21$.

Kahangama, K.G.D 2007.

Effects of root promoting hormones on vegetative propagation and salinity on seed germination of selected mangrove species. Unpublished undergraduate dissertation, Department of Botany, University of Kelaniya, Sri Lanka.

Lugo, A.E., M. Sell, \& S.C. Snedaker, 1976.

Mangrove ecosystem analysis. In:Systems Analysis and Simulation in Ecology (B.C. Patten ed.), pp.113-145, Academic Press, New Y ork.

Ong Jin-Eong, Gong Wooi Khoon \& B. F. Clough, 1995.

Structure and Productivity of a 20-Y ear-Old Stand of Rhizophora apiculata B1. Mangrove Forest. Journal of Biogeography 22(2/3): 417-424.

Okimoto Y., A. Nose, Y. Katsuta, Y. Tateda, S. Agarie \& K. Ikeda, 2007. Gas exchange analysis for estimating net $\mathrm{CO}_{2}$ fixation capacity of mangrove (Rhizophora stylosa) forest in the mouth of river Fukido, Ishigaki island, Japan. Plant Production Science 10(3): 303 -313.

Pahalawattaarachchi V \& M.D. Amarasinghe, 1995.

Structural and functional properties of mangrove ecosystems in Negombo lagoon, with reference to the implications of mangrove cultivation on lagoon productivity. A paper presented at the 
National Workshop on Mangrove Conservation. Forest Conservation Department, Sri Lanka.

Parida A.K. \& A.B. Das, 2005.

Salt tolerance and salinity effects on plants: a review. Ecotoxicology and Environmental Safety 60(3):324-349.

Rabinowitz, D, 1978.

Dispersal properties of mangrove propagules. Biotropica10 (1):47 $-57$.

Snedaker S.C. \& J.G. Snedaker, 1984.

Mangrove Ecosystem : Research Methods. UNESCO, Paris.

W oodroffe, C.D. 1993.

Geomorphological and climatic setting and the development of mangrove forests. In: Towards the rational use of high salinity tolerant plants. (H. Lieth and A.N. Masoom eds.), pp.13-24, Kluwer Academic Publishers, Netherlands. 